Flood of Images 
THIS PAGE INTENTIONALLY LEFT BLANK 


\section{Flood of Images}

MEDIA, MEMORY, AND

HURRICANE KATRINA

Bernie Cook

University of Texas Press 
Copyright (c) 2015 by the University of Texas Press

All rights reserved

Printed in the United States of America

First edition, 2015

Requests for permission to reproduce material from this work should be sent to:

Permissions

University of Texas Press

P.O. Box 7819

Austin, TX 78713-7819

http://utpress.utexas.edu/index.php/rp-form

(@) The paper used in this book meets the minimum requirements of ANSI/NISO Z39.48-1992 (R1997) (Permanence of Paper).

LIBRARY OF CONGRESS CATALOGING-IN-PUBLICATION DATA

Cook, Bernie, 1968-

Flood of images : media, memory, and Hurricane Katrina /

by Bernie Cook. - First edition.

pages $\mathrm{cm}$

Includes bibliographical references and index.

ISBN 978-0-292-77134-5 (cloth : alk. paper)

1. Hurricane Katrina, 2005-Press coverage. 2. Mass media-

Objectivity-United States. 3. Hurricane Katrina, 2005-Social

aspects. 4. United States-Social conditions-21st century. I. Title.

HV636 2005 .G85 C645 2015

$976^{\prime} .044-\mathrm{dc} 23$

2014026619

doi:10.7560/771345 
To my wife, Jen, and my children, Lucy and Emmett, my inspiration always. And to the people of New Orleans. 
THIS PAGE INTENTIONALLY LEFT BLANK 